\title{
PSYCHE
}

\begin{tabular}{lll} 
Vol 7I & SePtember, I964 No. 3 \\
\hline
\end{tabular}

\section{STUDIES ON NORTH AMERICAN CARBONIFEROUS INSECTS. 3. A SPILAPTERID FROM THE VICINITY OF MAZON CREEK, ILLINOIS (PALAEODICTYOPTERA) *}

\author{
By F. M. Carpenter \\ Harvard University
}

The Spilapteridae of the Order Palaeodictyoptera, although well represented in Carboniferous deposits of France (Commentry), Czechoslovakia (Moravia) and USSR (Asian RSFSR), has had only doubtful representation in Carboniferous strata of North America. Indeed, the only species that might possibly belong here is Mcluckiepteron luciae Richardson [Francis Creek shales of Illinois, near Mazon Creek] and its relationship to the family seems remote. Recently, I have had the opportunity of studying a new fossil from the same deposit; it is not only an unquestionable member of the family Spilapteridae but it seems to me to fall within the genus Homaloneura, already known from the Commentry shales in France. This fossil shows both fore and hind wings, with complete preservation of the venation as well as color markings, all in extraordinary detail.

I am deeply indebted to Mr. Walter Dabasinskas of Chicago for loaning me the fossil for study and for permitting me to prepare the fossil by removing the rock matrix which covered much of the wings. I am also grateful to Dr. Eugene Richardson of the Chicago Museum of Natural History for calling my attention to the existence of this fossil in Mr. Dabasinskas' collection and to Dr. Jarmila Kukalová, of Charles University in Prague (but currently visiting Harvard University), for the preparation of the excellent drawing on plate 16 .

*'This research has been aided by grant no. NSF GP-2038 from the National Science Foundation. The previous part in this series was published in Psyche 70:59-63. 

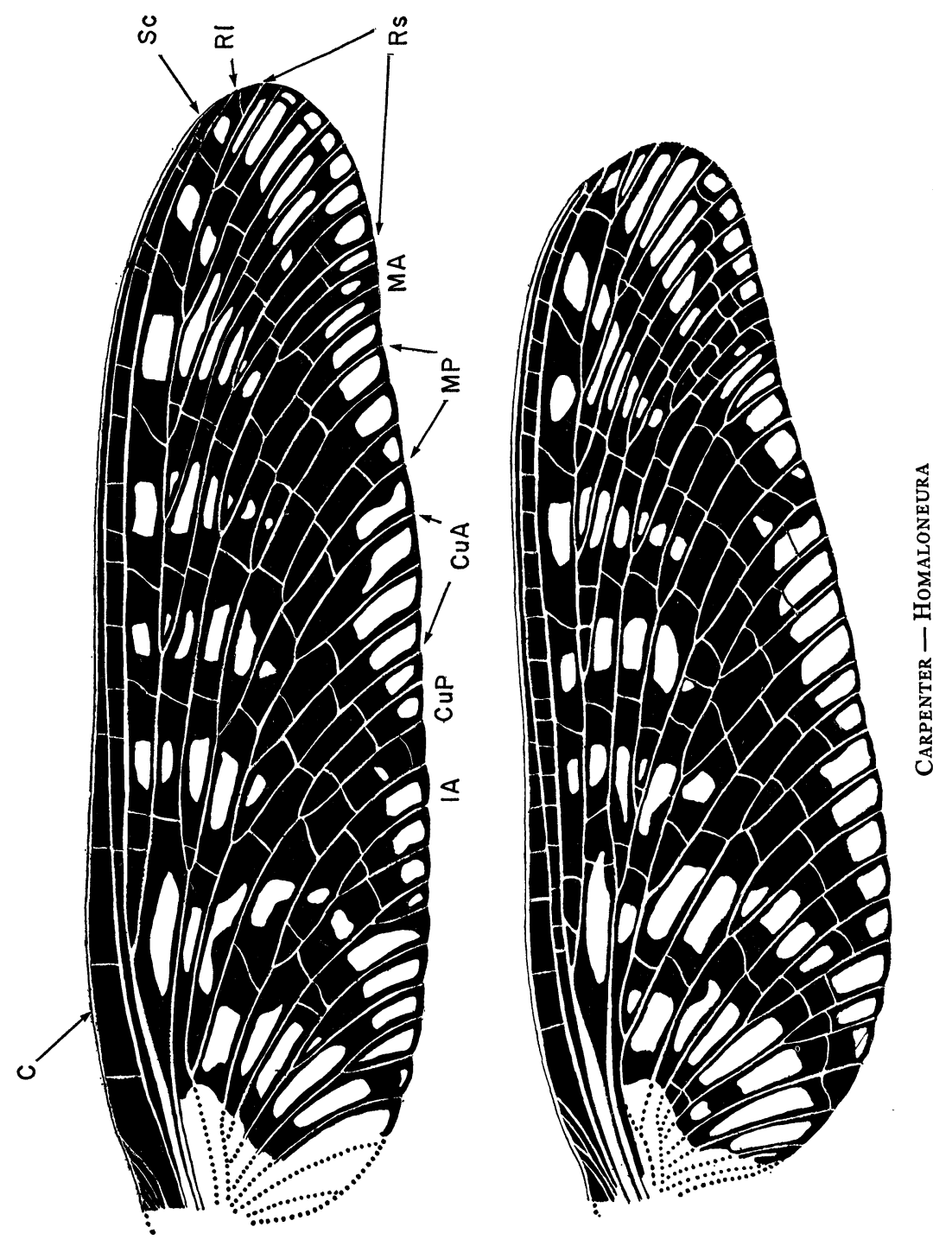
Order Palaeodictyoptera

Family Spilapteridae Handlirsch

Spilapteridae Handlirsch, 1906, Die fossilen Insekten p. 101.

The insects included in this family have distinct cross veins, which usually form definite rows; a true archedictyon is absent. The anterior margin of the wings (fore and hind) tends to be concave, often strongly so; the shapes of the fore and hind wings may be very similar (e.g., Homaloneura) but more often the hind wing has a broader cubital-anal region (e.g., Dunbaria); in such cases, although the cubitus and anal veins may have a few more branches than in the fore wing, the venation is essentially alike in the two wings. The radial sector has at least six terminal branches, both $\mathrm{MA}$ and MP have at least two branches, and $\mathrm{CuA}$ has several branches. The wings are commonly marked with bands or spots. The family is known from Upper Carboniferous strata to the Upper Permian. I consider the families Dunbariidae Handlirsch (1937), Doropteridae Zalessky (1946) and Neuburgiidae Rohdendorf (196I) to be inseparable from the Spilapteridae.

\section{Genus Homaloneura Brongniart}

Homaloneura Brongniart, 1885, Bull. Soc. Amis Sci. Natur. Rouen, 1885:5068 ; 1893, Recherches pour servir a l'histoire des insectes fossiles des temps primaires, p. 316.

Homaloneurina Handlirsch, 1906, Die fossilen Insekten, p. 46.

Homaloneurites Handlirsch, 1906, ibid., p. 47.

Homaloneura belongs to that series of genera of the Spilapteridae in which the subcosta etxends nearly to the apex of the wings and in which there is no anastomosis of $\mathrm{MA}$ with $\mathrm{Rs}$ (or $\mathrm{R}$ ) or of $\mathrm{CuA}$ with MP (or M). It is related to Doropteron (Permian, USSR), Permiakovia Martynov (Permian, USSR), Neuburgia Martynov (U. Carb., USSR) and Dunbaria Tillyard (L. Permian, Kansas). Unfortunately, our knowledge of even the wings of most of these genera is unsatisfactory; Permiakovia is known only from the hind wing and Doropteron and Neuburgia are known from the fore wings or parts of the fore wings. Some synonymy may eventually be necessary when more is known about these genera, but

Explanation of Plate 16

Homaloneura dabasinskasi, n.sp. Fore and hind wings; original drawing of holotype by Dr. J. Kukalová. C, costa $(+)$, Sc, subcosta $(-), R 1$, radius $(+)$, Rs, radial sector $(-)$, MA, anterior media $(+)$, MP, posterior media $(-), \mathrm{CuA}$, anterior cubitus $(+), \mathrm{CuP}$, posterior cubitus $(-), 1 \mathrm{~A}$, first anal $(+)$. 


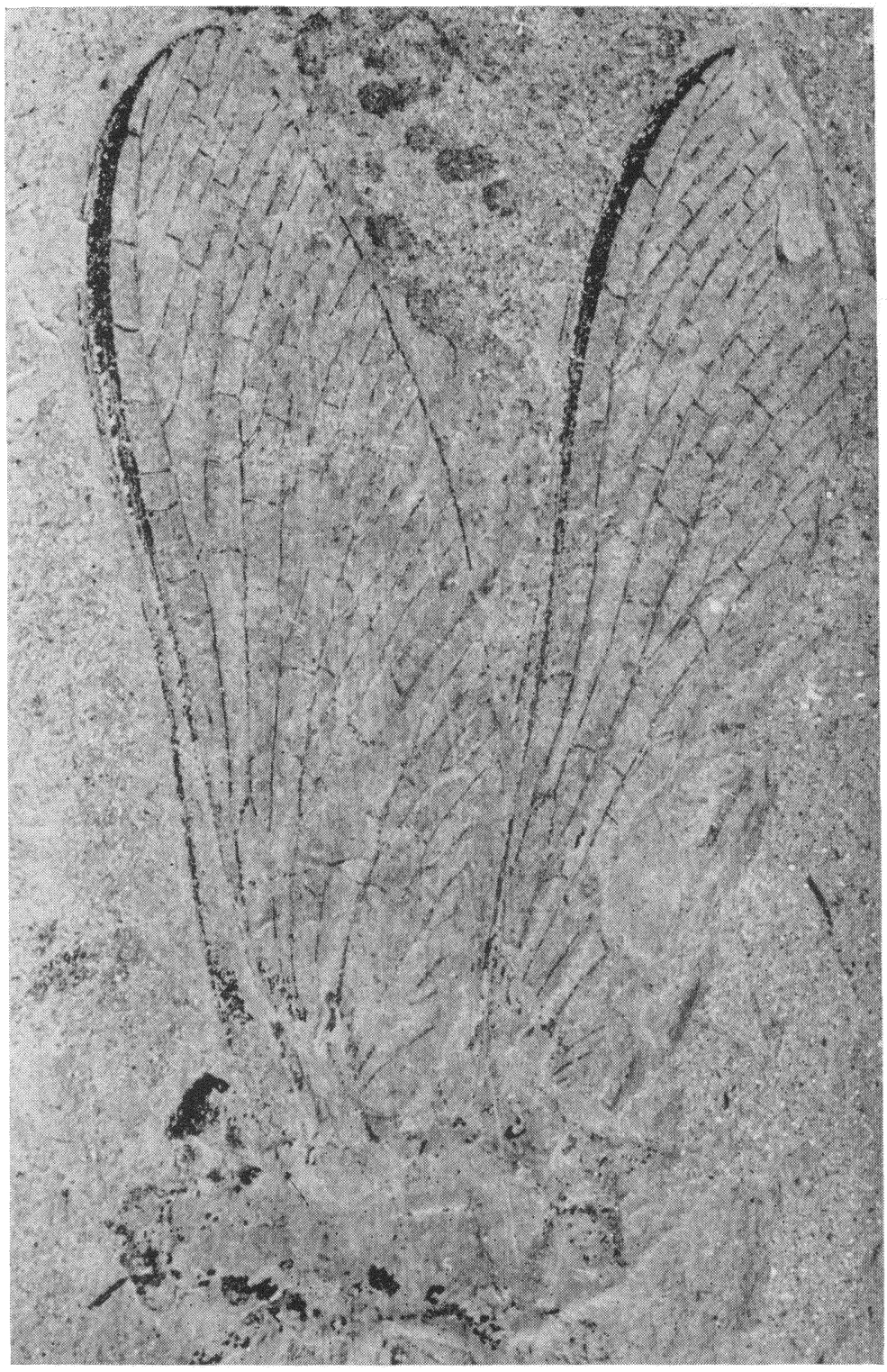


Homaloneura, being the first of this series to be described, will remain valid. It is distinguished from the other genera of the Spilapteridae in having the concavity of the front margin of both fore and hind wings very slight and in having the anal region of the hind wing much less extensively developed than in the other genera in which the hind wing is known. Homaloneura elegans Brongniart was designated the type-species of the genus Homaloneura by Handlirsch in I922; a photograph of the type specimen of elegans is given on plate 17 of the present paper.

\section{Homaloneura dabasinskasi, n. sp. Plates 15 and 16}

Fore wing: length, $55 \mathrm{~mm}$.; maximum width, $15 \mathrm{~mm}$. Costal margin very slightly concave, apex of wing rounded, hind margin with two slight indentations, one near the posterior branch of MA and the other near the anterior termination of MP. Costal space broad in the basal half of the wing but narrowing abruptly towards the middle of the wing and continuing of uniform width for the rest of the wing until the termination of Sc, just before the apex; $\mathrm{R}$ and RI nearly parallel to Sc; Rs arising about a quarter of the wing length from the base, dividing to form five main branches, about half of which fork once again; the branches of Rs tending to arise more dichotomously than pectinately; $M$ arising from the base of the wing as an independent vein, forming MA and MP slightly distally of the origin of Rs; MA with three terminal branches; $\mathrm{MP}$ with four; $\mathrm{Cu}$ apparently arising independently from the wing base, forking very shortly into $\mathrm{CuA}$ (with four branches) and $\mathrm{CuP}$ (forked). The basal connections of the anal veins are not clearly preserved; the first of these terminates in three branches, the next three are forked. Cross veins distinct, arranged as shown in plate I6. The wing is distinctly marked with transverse bands and spots.

Hind wing: length, $50 \mathrm{~mm}$.; maximum width, $18 \mathrm{~mm}$. This is shaped like the fore wing except that the concavity of the costal margin is slightly more pronounced and the anal area is somewhat more rounded. The number of anal veins appears to be the same

Explanation of Plate 17

Homaloneura elegans Brongniart, U. Carboniferous, Commentry, France. Photograph of type in Laboratoire de Paleontologie, Paris. (Original). $\times 4$. Note the prothoracic lobes and the similarity of the wing venation to that of $H$. dabasinskasi. The posterior margin of the hind wing is incompletely preserved. 


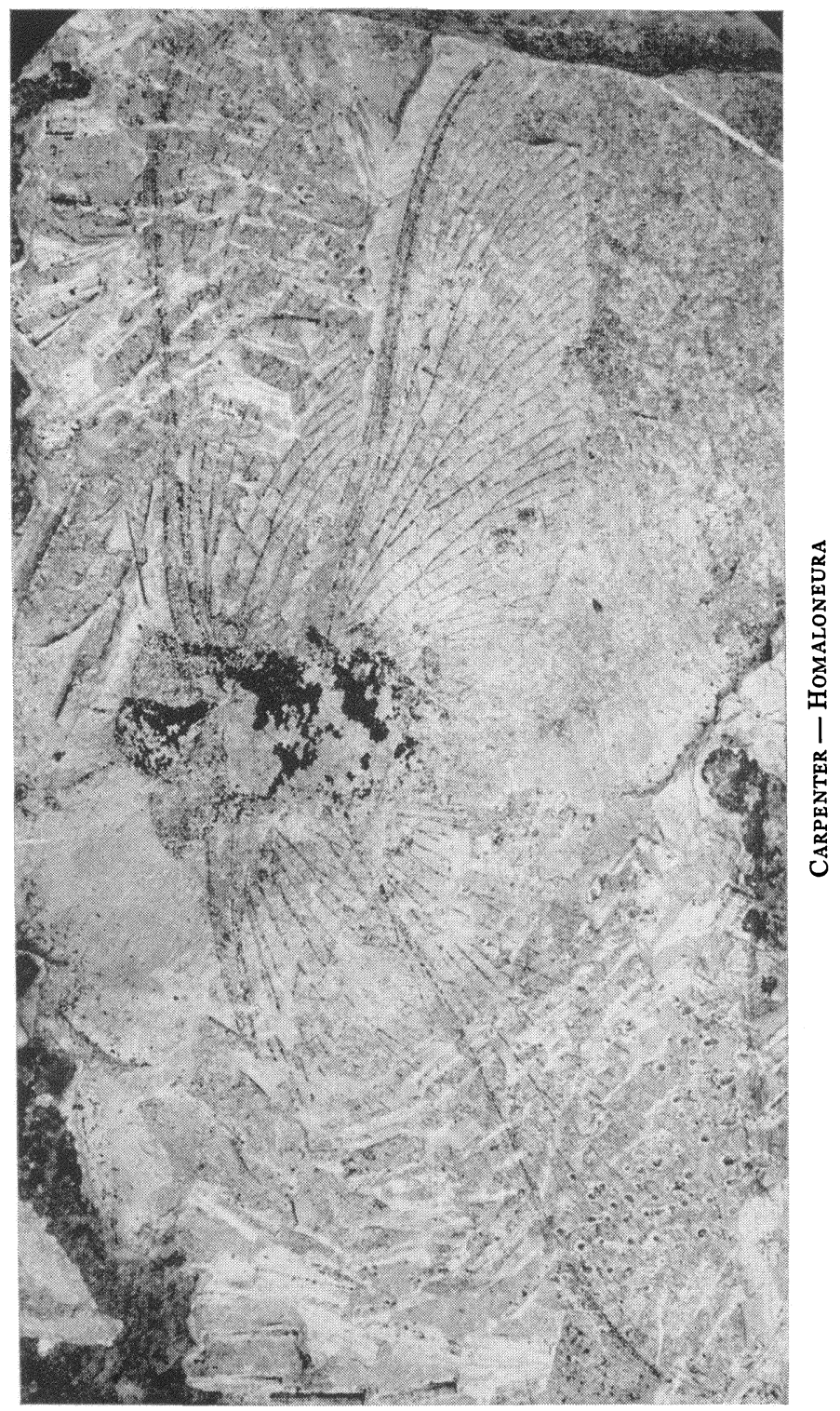


in both wings. The venational pattern is basically as in the fore wing, with only slight differences in the positions of the branches, mainly those of the radial sector. The wing markings and cross veins are essentially as in the fore wing.

Holotype: collected by Mr. Walter Dabasinskas in June, I960, in an ironstone nodule, found at the Greer Earthmoving and Mechanics School, Will County, Illinois, 4 miles north of Braidwood. The type is contained in Mr. Dabasinskas' collection and the species is named for him. This fossil is the most spectacularly preserved fossil insect which I have ever seen in a nodule from the Mazon Creek region and it is indeed one of the striking Carboniferous insects known to me. As can be observed in the photograph (plate 15) the fore wing is posterior in position to the hind wing and the apex of the fore wing rests near the base of the hind wing. That these two wings were derived from one side of the same specimen of an insect seems almost certain. The subcosta is concave in one wing and convex in the other; presumably, the wings broke away from the body as the insect rested in water and one of the wings turned over as well as rotating through $180^{\circ}$ before coming to rest in the mud. The counterpart of the half of the specimen shown in plate 15 has the apex of the fore wing and basal region of the hind wing completely preserved.

A comparison of the wings of dabasinskasi with those of $H$. elegans and the other Commentry species shows enough differences to require a distinct species for the new fossil but not enough in my opinion to justify generic separation. The hind margin of the fore wing of dabasinskasi is somewhat more sharply curved basally than in the Commentry species. The wing markings of dabasinskasi are distinctly different from those of elegans, which has a dark, longitudinal stripe along R I distally; but they are similar to those of another Commentry species, H. ornata Brongniart.

In addition to the features mentioned above as specific in nature, several other structures preserved in this new fossil deserve mention, since they may turn out to be common to all Spilapteridae and perhaps to other families of the Palaeodictyoptera. One of these is the series of fine ridges at the base of the costal area of both fore and hind wings (see plate 16 ). These do not appear to be veins in

Explanation of Plate 18

Homaloneura bonnieri Brongniart, U. Carboniferous, Commentry, France. Photograph of type in Laboratoire de Paleontologie, Paris. (Original). $\times 2$. Note the prothoracic lobes and the similarity of the hind wing to that of $H$. dabasinskasi. 
this species and the more basal area cannot be considered as a precostal area, as it occurs in the Orthoptera or Protodonata. Since similar ridges or actual veinlets have been observed (Kukalová, 1960) in other Palaeodictyoptera (Breyeria and Ostrava), they may turn out to be characteristic of most Palaeodictyoptera. Another interesting structure present in dabasinskasi is the thickened basal stem of $\mathrm{R}$. Examined under certain angles of illumination, the posterior edge of this stem appears as an independent vein extending almost from the base of $M$ to the origin of Rs. Careful examination of the base of the wing, under various types of illumination, however, has convinced me that this apparent vein is actually the posterior edge of the stem of R. Similar widening of R can be seen in the Commentry specimens of Homaloneura.

To enable further comparisons of dabasinskasi with the described species of Homaloneura, I am including here (plates I7 and I8) photographs of the types of $H$. elegans Brongniart and of $H$. bonnieri Brongniart, which are contained in the Laboratoire de Paleontologie of the Museum National d'Histoire Naturelle, Paris. It is regrettable that the Illinois fossil does not show such body structures as the prothoracic lobes, which are visible in both of the Commentry fossils depicted.

\section{ReFERENCES}

Brongniart, C.

1885. Les insectes fossiles des terrains primaires. Bull. Société Amis des Sciences Naturelles de Rouen, 1885: 50-68.

1893. Recherches pour servir á l'histoire des insectes fossiles des temps primaires. Saint-Etienne, pp. 1-493.

HANDLIRSCH, A.

1906. Die fossilen Insekten, Leipzig, p. 108.

1922. Fossilium Catalogus, (1) 16: 47.

KuKaLOVÁ, J.

1960. New Palaeodictyoptera (Insecta) of the Carboniferous and Permian of Czechoslovakia. Sbornik UUG, paleon. $25: 239-250$. ROHDENDORF, B. B.

1961. Palaeozoic insects of the Kuznetsk Basin. Trudy Paleont. Inst., $85: 72$.

ZALESSKY, G.

1946. Sur un représentant d'un nouveau ordre des Hemiodonates de Perimien de l'Oural. Bull. Soc. Nat. Moscou, 51 : 63-70. 


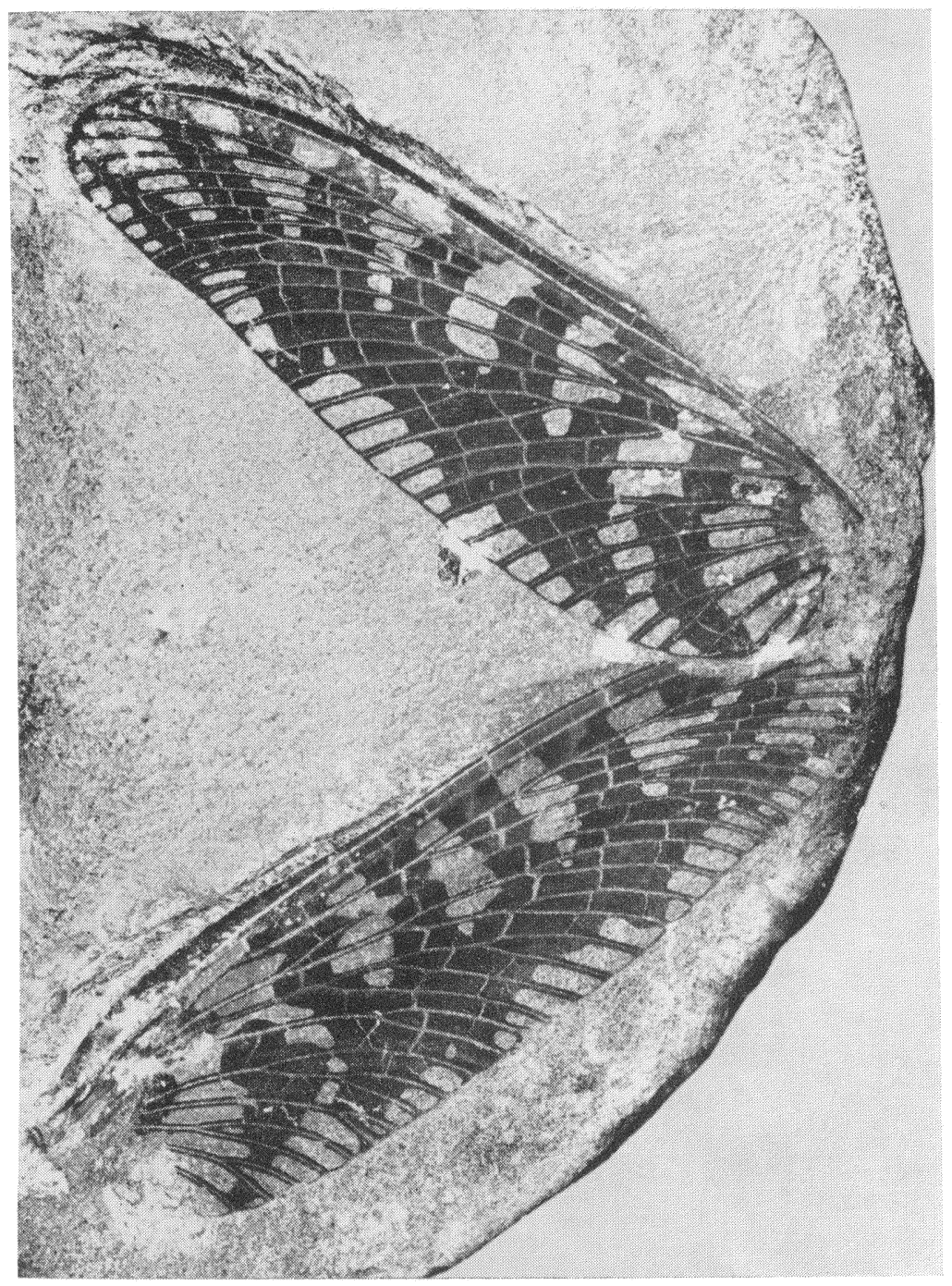

Homaloneura dabasinskasi, n.sp. Photograph of holotype (original). $\times 2$. The fore wing is the lower of the two wings. 

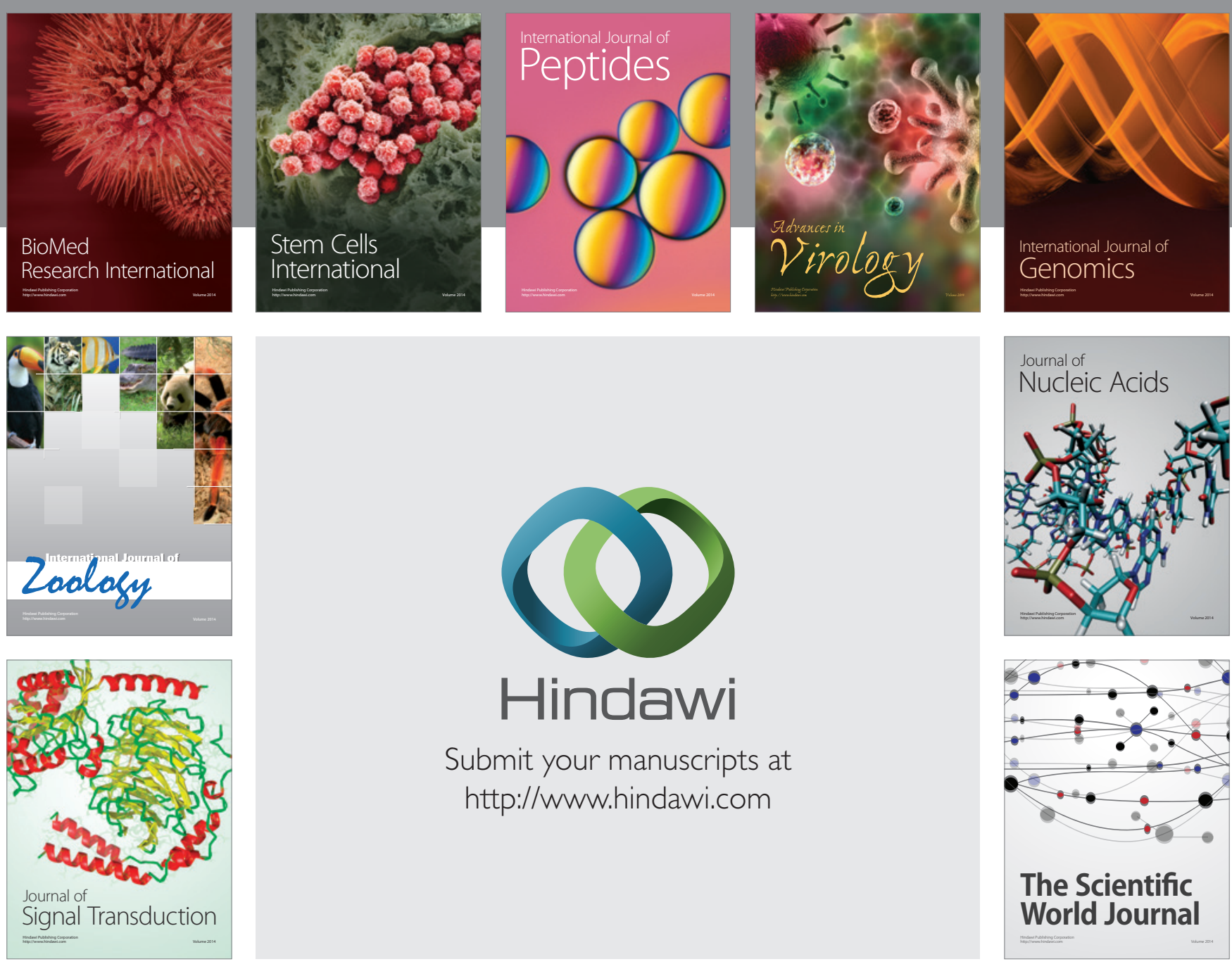

Submit your manuscripts at

http://www.hindawi.com
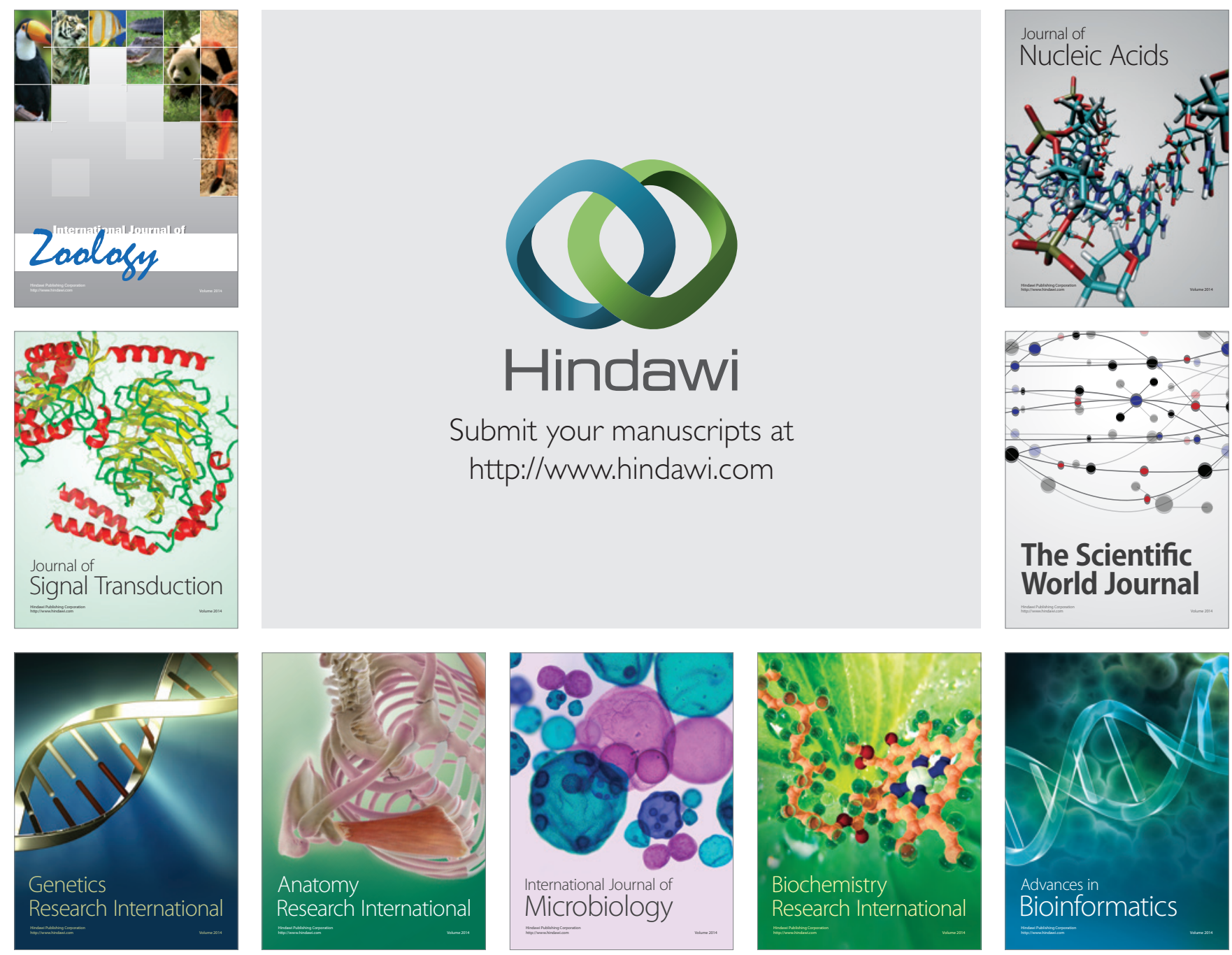

The Scientific World Journal
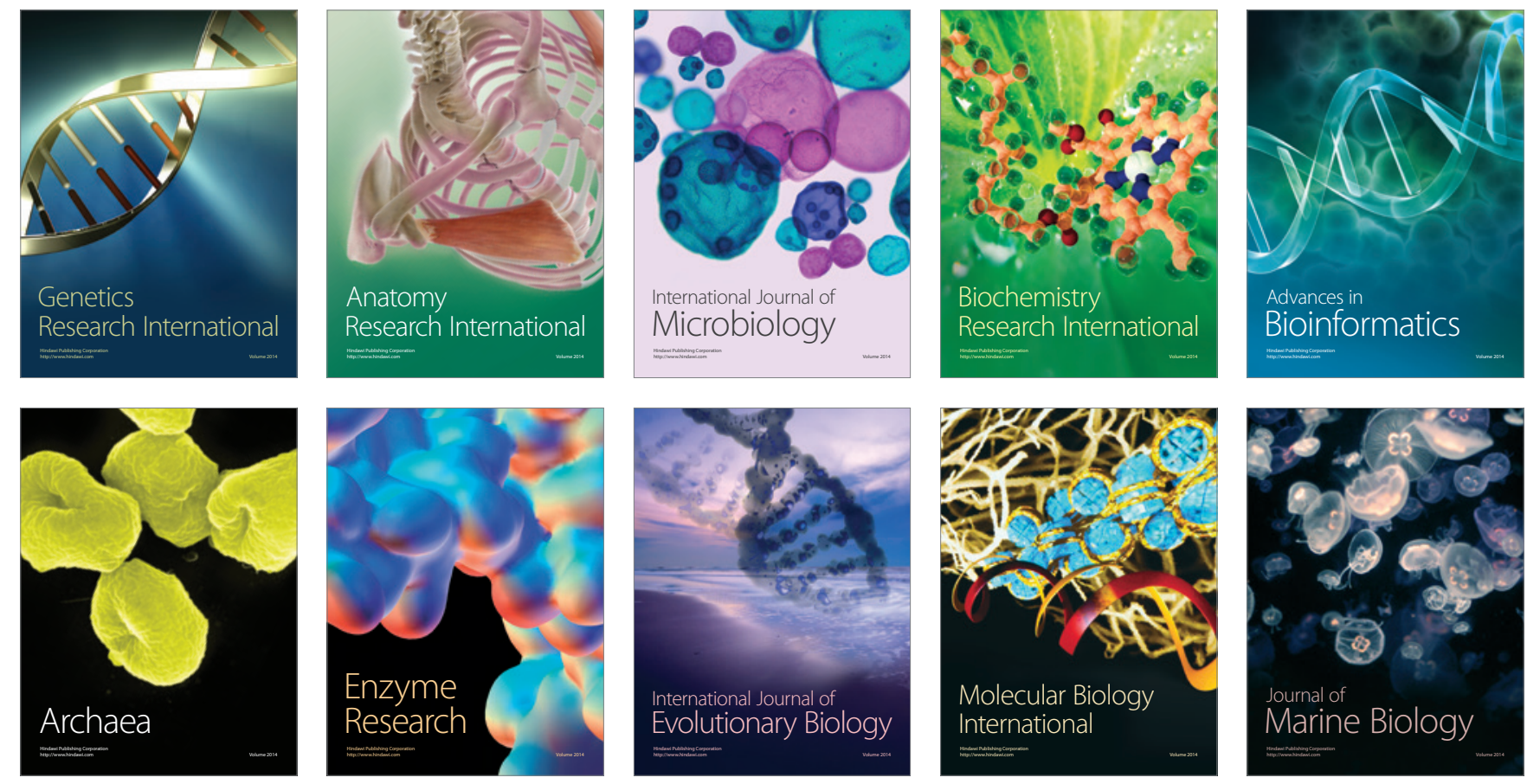